sanctuary. Puffins, razorbills, common and black guillemots, fulmars, shags, kittiwakes and herring and great black-backed gulls all breed there. A grant from the Helena Howden. Trust has enabled the Society to repair and furnish the bothy on the Island to provide accommodation for up to six members wishing to stay there to watch and study the birds. Bookings should be made through the Society's Scottish Office, 21 Regent Terrace, Edinburgh 7. Access is by fishing boat from Tarbet or Scourie, and there are no restrictions on landing.

\section{The Lundy Field Society}

THE fourteenth annual report of the Lundy Field Society includes a list of the birds recorded during the year, the species ringed during 1959, 1960 and 1961, and some interesting ornithological notes on the more unusual observations (Pp. 40. Barnstable: Hon. Secretary, Lundy Field Society, 8 Rock Avenue, 1962). It is also of importance to note that fourteen recoveries have been made of ringed birds, two having reached the U.S.S.R. There is a preliminary account of the archæological investigations in the "Bulls Paradise" by Mr. K. S. Gardner and a report on the discovery of the 'Tulocus' Stone in Beacon Hill Cemetery.

\section{The International Congress of Mathematicians (Edinburgh) Fund}

THe British National Committee for Mathematics has been asked by the Trustees of the International Congress of Mathematicians (Edinburgh) Fund to allocate grants from the Fund for the following purposes: $(a)$ award of travel grants to mathematicians in the United Kingdom to attend international conferences; $(b)$ donations to mathematical symposia, meetings or conferences to be held in the United Kingdom. Applications in respect of $(a)$ should be made on forms of application obtainable from the Executive Secretary of the Royal Society (Burlington House, Piccadilly, London, W.1). Applications in respect of $(b)$ should be submitted by letter to the Executive Secretary of the Royal Society, supplying the following information: (i) name and address of sponsoring organization; (ii) details of proposed scientific meetings: (a) place, (b) dates, (c) total amount of financial assistance required; (iii) brief statement of scientific programme of the meeting including principal speakers; (iv) exact purpose for which grant is required (giving estimates with details where possible); (v) whether the applicant has applied for assistance from any other source and, if so, with what results. Applications in respect of $(a)$ or $(b)$ should be sent to the Executive Secretary by December 31 .

\section{The Cement and Concrete Association's Training Courses}

THE Cement and Concrete Association has issued its prospectus and programme, Training Courses in Concrete, for 1963. The Association's courses, held at their Training Centre and Research Station at Wexham Springs in Buckinghamshire, are well known as an integral part of the training of those concerned with the design, making or placing of conerete. The programme of courses offered in 1963 follows a similar pattern to previous years, but a new feature is the appearance of two combined courses and overseas visits, one for architects, the other for engineers concerned with motorway and major road construction. Participants on these courses will spend two days at the Training Centre and the remainder of the week visiting outstanding jobs on the Continent. Copies are obtainable from the Training Centre, Cement and Concrete Association, Wexham Springs, Framewood Road, Stoke Poges, Slough, Bucks.

\section{Announcements}

Dr. E. M. PATTERson, senior lecturer in mathematics in the University of A.berdeen, has been awarded the Makdougall Brisbane Prize for the period 1960-62 by the Royal Society of Edinburgh, for his papers on linear algebras published in the Proceedings of the Society during the period of the award and earlier papers on cognate subjects published by the Society.

Entries are invited for the 1963 Maccabaean Prize of 25 guineas and a bronze medal, which is awarded annually by the Faculty of the History of Medicine and Pharmacy of the Worshipful Society of Apothecaries of London. Competitors, who must be under thirty years of age on March 15, 1963, will be required to submit before that date an essay of not more than 6,000 words on any subject connected with the history of medicine or pharmacy. Entry forms and further information can be obtained from the honorary secretary of the Faculty, Dr. F. N. L. Poynter, the Wellcome Historical Medical Library, the Wellcome Building, Euston Road, N.W.1.

THE eleventh inter-university geological congress on "Geological Aspects of Commonwealth Economy" will be held at University College, Cardiff, during January 3-5. Further information can be obtained from K. Howells, Department of Geology, University College, Cathays Park, Cardiff.

A Symposium on "The Evaluation of the Degree of Hydrogen Bonding in Biological Molecules", supported by the British Biophysical Society, will be held at the South-West Essex Technical College and School of Art, Walthamstow, on February 16. The opening lecture will be delivered by Prof. J. A. V. Butler. Further information can be obtained from Dr. S. Lewin, South-West Essex Technical College and School of Art, Forest Road, Walthamstow, London, E.17.

Postaraduate courses in "Inorganic Stereochemistry" and "Nuclear Metallurgy", suitable for graduates and research workers in the fields of chemistry and metallurgy, will be held at Brunel College. The first course will consist of seven lectures to be given on consecutive Mondays commencing on January 14, and the second of nine lectures, to be given on consecutive Thursdays commencing on January 10. The fee for each course will be $£ 1$. Further information and forms of application can be obtained from the Registrar, Brunel College, Woodlands Avenue, Acton, London, W.3.

THE fourteenth Pittsburgh conference on "Analy tical Chemistry and Applied Spectroscopy" will be held in Pittsburgh, Pennsylvania, during March 4-8. The programme will include symposia on: solution techniques in X-ray and emission spectroscopy; techniques related to infra-red spectroscopy; nuclear magnetic resonance--nuclei other than hydrogen; gas chromatographic analysis of metallo-organics and related compounds; uses of reaction-rates in analytical chemistry; the analysis of refractory metals. Further information can be obtained from the programme chairman, Dr. W. A. Straub, Applied Research Laboratory, United States Steel Corporation, Monroeville, Pennsylvania. 